\title{
Serine/Threonine-Protein Phosphatase 2A 65 kDa Regulatory Subunit A Alpha Isoform
}

National Cancer Institute

\section{Source}

National Cancer Institute. Serine/Threonine-Protein Phosphatase 2A 65 kDa Regulatory

Subunit A Alpha Isoform. NCI Thesaurus. Code C92538.

Serine/threonine-protein phosphatase 2A $65 \mathrm{kD}$ a regulatory subunit A alpha isoform (589 $\mathrm{aa}, \sim 65 \mathrm{kDa}$ ) is encoded by the human PPP2R1A gene. This protein is involved in the regulation of protein phosphatase $2 \mathrm{~A}$ complex assembly. 